\title{
Interaction of Urobilinogen with Body Sweating
}

Research Article

Muhammad Imran Qadir \& Muhammad Asad, Maleeha Azhar*

Institute of Molecular Biology and Biotechnology, Bahauddin Zakariya University, Multan, Pakistan.

Corresponding Author

Author Email:

maleeha.azhar1998@gmail.com

\section{INTRODUCTION}

Urobilinogen is by product of
Abstract: Objective of the present research was to relate body sweating with urobilinogen. Urobilinogen is reduced form of urobilin. Urobilinogen increases with hemolytic anemia. Through urine test we can measure the amount of urobilinogen in urine. Basically it is a product of breakdown of hemoglobin into red blood cells. Small amount of urobilinogen is present in urine. Sweating is basically a fluid secreted by sweat glands of body.it helps in performing thermoregulation. Sweat is composed of $99 \%$ of water and $1 \%$ salt and fat. Sweating helps in losing weight. Having more than normal body sweating is not harmful but having no sweat has somehow its effects. A total of 100 subjects participated in this study. The subjects were students of Bahauddin Zakariya University Multan, Pakistan. It is concluded that there is association between urobilinogen and body sweating.

Keywords: Urobilinogen, Interaction, Body Sweating.

bilirubin which is color less. Bilirubin is yellow in color and present in liver. It is designed by an action of bacteria in intestines. Half of this is reabsorbed by portal vein and is excreted by kidney. Basically it is a product of breakdown of hemoglobin into red blood cells. Small amount of urobilinogen is present in urine. In obstructive jaundice bilirubin is also disturbed results in foul excretion of urobilinogen. Urobilinogen is reduced form of urobilin. Urobilinogen increases with hemolytic anemia. Through urine test we can measure the amount of urobilinogen in urine. Amount of urobilinogen in urine must be normal. Less or no amount of urobilinogen also too much amount of urobilinogen in urine indicates that liver is not working well.

Body sweating is necessary. Because it helps in cooling body to maintain temperature of inner body with outer environmental temperature. Thus preventing us from overheating. Sweating is also called by perspiration. Sweating is basically a fluid secreted by sweat glands of body.it helps in performing thermoregulation. Sweat is composed of $99 \%$ of water and $1 \%$ salt and fat. Sweating helps in losing weight. Having more than normal body sweating is not harmful but having no sweat has somehow its effects. Eccrine glands and apocrine glands helps in secretion of sweat.

Objective of the present study was to relate body sweating with urobilinogen.

\section{MATERIALS AND METHOD}

A total of 100 subjects participated in this study. The subjects were students of Bahauddin Zakariya University Multan, Pakistan. A urine test was performed by taking some amount of urine in container and urobilinogen in it was measured by using strip which shows color on different range.

\section{Project Designing}

A questionnaire was prepared to show any relation between body sweating and urobilinogen. Subjects were allowed to perform urine test. 


\section{STATISTICAL ANLYSIS}

We calculated percentage to evaluate results.

\section{RESULTS AND DISCUSSION}

Association between body sweating and urine urobilinogen is given in table 1 .

It was calculated from the table that $7 \%$ females with body sweating had negative values for urine urobilinogen but $18 \%$ had positive values. And 13\% females with no body sweating had negative values for urine urobilinogen but $37 \%$ had positive values.3\% males with body sweating had negative values for urine urobilinogen but $8 \%$ had positive values. And 5\% males with no body sweating had negative values for urine urobilinogen but $9 \%$ had positive values.

Table 1: Percentage between body sweating and urine urobilinogen.

\begin{tabular}{|c|c|c|c|c|}
\hline & BODY & BODY & BODY & BODY \\
\hline UROBILINOGEN & SWEATING & SWEATING IN & SWEATING IN & SWEATING IN \\
\hline \multirow[t]{2}{*}{ IN URINE } & IN FEMALES & FEMALES & MALES & MALES \\
\hline & (YES) & (NO) & (YES) & (NO) \\
\hline$-\mathrm{Ve}$ & $7 \%$ & $13 \%$ & $3 \%$ & $5 \%$ \\
\hline$+\mathrm{Ve}$ & $18 \%$ & $37 \%$ & $8 \%$ & $9 \%$ \\
\hline
\end{tabular}

\section{CONCLUSION}

It is concluded that there is association between urobilinogen and body sweating.

\section{REFERENCES}

1. Qadir MI, Javid A (2018) Awareness about Crohn's Disease in biotechnology students. Glo Adv Res J Med Medical Sci, 7(3): 062-064.

2. Qadir MI, Saleem A (2018) Awareness about ischemic heart disease in university biotechnology students. Glo Adv Res J Med Medical Sci, 7(3): 059-061.

3. Qadir MI, Ishfaq S (2018) Awareness about hypertension in biology students. Int J Mod Pharma Res, 7(2): 08-10.

4. Qadir MI, Mehwish (2018) Awareness about psoriasis disease. Int J Mod Pharma Res, 7(2): 17-18. 
5. Qadir MI, Shahzad R (2018) Awareness about obesity in postgraduate students of biotechnology. Int J Mod Pharma Res, 7(2): 14-16.

6. Qadir MI, Rizvi M (2018) Awareness about thalassemia in post graduate students. MOJ Lymphology \& Phlebology, 2(1): 14-16.

7. Qadir MI, Ghalia BA (2018) Awareness survey about colorectal cancer in students of M. Phil Biotechnology at Bahauddin Zakariya University, Multan, Pakistan. Nov Appro in Can Study, 1(3): NACS.000514.2018.

8. Qadir MI, Saba G (2018) Awareness about intestinal cancer in university student. Nov Appro in Can Study, 1(3): NACS.000515.2018. 